\title{
The Concept of Blood Money and Retribution in Islam
}

\author{
Mohamad Reza Momeni \\ Department of low. Abarkooh branch. Islamic Azad university. Abarkooh. Iran
}

\begin{abstract}
The reason to investigate the present issue and its aspects raised from the fact that there is still no consensus in the legal system of the Islamic Republic of Iran, regarding the criminal or civilian aspect of the Blood Money, and this not only in the legal level, but at the level of the judiciary and courts, has a practical and objective effect. If we take a look at the history of the blood money and its emergence, we find that this was the establishment of a legal remedy for the damage sustained against him/his parents, and in fact, we were victimized for blood, and he was more private in nature, but with the formation of governments, this situation was taken from the blood and tried to give a color of punishment to this legal foundation. Thus, it became clear that the blood money actually had a mixed and two-dimensional nature, that is, on the one hand, it should be used to compensate for the death of the victim or the innocent, on the other hand, it is a penalty that has been imposed upon him and should be enforced against him. This is the point that the Islamic Republic of Iran's penal code has accepted it. On the other hand, the current Iranian law has used the Islamic jurisprudence to conclude that life is responsible for the loss of excessive damage to the money that has been inflicted on the injured party and should be compensated for it, and it should be considered that the non-acceptance of damages and damages the surplus on the money indicates that the society is not paying attention to the facts of justice and justice, and finally it has been proved that the prescribed values of the six-year blood money can be used to compensate for the loss of harm to the victim in the form of money in any Islamic country. The order of the implementation of religious laws is to be achieved with the requirements of time and place.
\end{abstract}

DOI: $10.7176 /$ RHSS/9-12-10

Publication date: June $30^{\text {th }} 2019$

\section{Introduction}

Blood money is a legal entity in the current legal system of Iran, which is rooted in Islamic jurisprudence and its criminal laws, and has features and characteristics that are debatable and can lead us to a deep and accurate understanding of this Islamic legal foundation. The word blood money is mentioned only twice in the Holy Qur'an in verse 92 of Nisa'ah, which says:

"And we have been warned that there is no error in the matter and that the death of the believer and wrongdoing are caused by the death of the believer and the tribe of the people of the land and of the people of the land and of the people of the land. The land and writing of the rival of the believer". It means that there is no believer who kills a believer unless he makes a mistake, and if he kills a believer in error, he should release the believer and give blood money to the blood owner. As it is deduced from the content of this verse, the amount of dye was not determined in the Holy Qur'an, but it was expressed in the form of the "Muslem blood money", and the blood money was known before Islam, but it was not a single amount, and its quantity and ratio, on the one hand, the soul and mindset of the bloodthirsty people, on the other hand, depended on the personality of the innocent and so on, and the passing of the victim's family from the tribe is an acceptable and acceptable act of God, and the wording is that it is not necessary to pay a contingent payment on the request of the victim's family.

\section{Legal Concept}

Abdul Qadir Odeh stated in the definition of blood money that:

"blood money is the first successor to punish retribution. Therefore, if the retribution, which is the basic punishment, is not respected or abandoned, the payment of a punishment will be proved, and this will not be forgiven. The blood money is like punishment for the crime of a member, and if it takes the place of retaliation, he will be a punishment. "

Another lawyer says about blood money:

"Death penalty is a financial liability for intentional offenses against the soul or the members of the human family, and this is a fundamental punishment if the injured person, or if he wants to, while the retribution is not ready." Another jurist says about blood money:

"It is a money that is given to the innocents or owners of blood to satisfy their pleasure, and we are for the murder of a soul or a member."

One of the Iranian jurists believes in blood money stated that:

"The financial compensation that a person must pay for unnatural crimes is called "blood money". Similarly, in deliberate crimes, if civilians or their peacekeepers seek financial compensation instead of retalation, the amount of compensation in the Islamic law is often determined, but the innocent or his parents can be peaceful in terms of 
bounty".

Dr. Parviz Sanei about blood money stated that:

" blood money is a financial or cash penalty that must be paid in three cases."

\section{The Legal Concept of Money}

" blood money is financially given to a person or a member of the criminal against him or herself or his parents." The application of this article is inconsistent with the provisions of Article 367 of the Criminal Code, since in the definition of the above, the appreciation and determination of the amount of blood for its diagnosis is necessary.

Article 367 states: "Any crime committed against a person who has not been given a specific amount as a payment for it is a matter of concern."

However, according to the articles 367 and 481 of the Islamic Republic of Iran, and Islamic sources, if the amount we have not been determined by the taxpayer for financial crimes against human beings is paid by the government. The material has eliminated the prejudice raised in Article 15 of the Criminal Code, and since human interests are also the subject of crime, in addition to human beings and human beings, the legal problem has been eliminated in this regard. It seems that the differences in the abovementioned materials are due to the adherence of the authors of the law to some of the jurisprudential books, as it is stated in Jahar al-Klam:

The term " blood money " is obligatory for committing a crime on the self or members, whether it is foreshadowing or not intended, and maybe the term " blood money " refers to cases that are definite and predestined. Given the above, the definition that I can legally give to the dying and the guidance of future lawmakers of our country in this regard is as follows: " blood money is financially paid by virtue of a crime against the self or the members or interests of his innocent or his deputy".

\section{Iranian Criminal Law \\ Before the Islamic Revolution of Iran}

From the works and documents obtained and the remaining inscriptions from the time of Islam, ancient kingdoms gave great importance to the judiciary and committed to the establishment and implementation of justice and justice because they knew well that the provision of judicial justice in the country for Persistence and preservation is necessary. The first line of the kings of Iran has therefore been named by the Prophets who have been in the process of law and development of justice and advancement.

In pre-Islamic Iran, there was no definite definition of crime, but according to the documents obtained from this time, we can say that there are various types of crime without a specific classification, and according to these types of crime, the king and the family or the people of the people. The diagnosis of this injury is often determined by the recognition of the king or judges of the king. At that time, the king was in charge of responsibility, but at the same time he was the manifestation of justice and the reference to public indemnity. People associate the judiciary with him and asked him to bring justice. The king's will alone was sufficient to convey sentences of condemnation. No one had the right to object to the sentences handed down by him. In the Inscription of Rostam, quoted by King Darius of Achaemenid king:

"Anyone who harasses me punishes me according to the harassment he has committed."

The entry of Islam into Iran has begun a major and fundamental change in Iran's criminal law since Iran is fully prepared to accept progressive and new ideas for the advancement and understanding of the institutions of Islam. Islamic law in the field of delinquency and dealing with it has unique innovations, for example, regarding criminal responsibility in all crimes of puberty and wisdom and development, and intention and will in the execution of punishment. The penalties are categorized accurately and precisely. The procedures are simple and quick, and the judge's circumstances and the exact judgment method. With these interpretations, Islam's criminal law is based on three general principles:

1. Principle of the existence of penalties

2. Principle of personal punishment

3. Principle Equalization of Punishment

By recognizing these principles, we explain and explain them in an Islamic perspective, respectively.

1. The principle provides for punishments for most offenses, such as those related to punishments and retaliation for certain offenses, and according to which the punishment for such offenses is specified and punishments for certain offenses are not taken into account. Like the ta'zirat, which leads to rebuking and killing, and its determination has been left to the ruler.

The principle is the personal responsibility of individuals for crimes. In this article, the verses 56 and 57 of the Hajj chapter, verses 35 and 45 of Surah al-Fatir, verses 19 and 95 of the surah of Maryam, verses 38 and 40 of Surah al-Najm and verse 88 of surah al-Shaara are mentioned. In Islam, everyone is responsible for his actions. According to the rule of wickedness in Islam, one should not tolerate the loss and harm of others, and therefore only the culprit is punished and no one is responsible for his actions. This principle, although limited in some cases, such as the establishment of a reasonable sanction, but in the specific sense of punishment, this principle is still 
important and valuable.

The above principle indicates that in Islam, the importance and value of individuals to their virtues, and not to their dignity and Muslims are brothers, and if there is a penalty for anyone, this is a punishment for all who do so, not for a particular person or a class However, this principle governs only the relations of Muslims with each other, and in the case of non-Muslims, this principle is not fully enforced. For example, the murder of a Muslim man by a Muslim man is punishable by retaliation, but if a Muslim man kills a Christian man, the only decree of death he is exported to him and only in the habit of murdering men or followers of Christ, his retribution is given to his retribution.

Before the proclamation of constitutionalism in Iran, the influential and masters of power, without recourse to the religious or customary courts, punished the culprits. Trust al-Saltanah expresses an example. He who considers himself a scientist and a goddess is a gardener, flogging Aqdariyah for a small 500 sins and expelling him. Nasser-al-Din Shah faced the noise of people when he was walking to Sultan Abad. There was a false confession of the defendants, which was due to Amir Akhour's chastity. He had enough of him to die so much.

After the Constitutional Revolution, there will be a fundamental and important development in the Iranian society, and people and liberators will find the readiness to accept and accept and analyze new and new thoughts in all aspects of the law, in particular. The rule of law in Iran is on two levels: a theoretical level, which is represented by intellectuals such as Mirzamalkam Khan and Meskaraddoleh and Talebov Tabrizi.

The second is the level of action that most of the attention is given to the law in the heart of the government apparatus, that is, those who wanted to constrain the behavior of government officials and propose laws. Mirzamalkam Khan had read French law and considered it the mother of all sciences. He sets out the theory of separation for the first time. There he speaks of the Legislative Assembly and the Council of Ministers. Parliament adopts the law and executes it by the Council of Ministers. Indeed, the constitutional revolutionary movement was an effort that had already been made to carry out the modernization of the administrative and executive apparatus. Since 1850, the attention of intellectuals and constitutionalists has focused on the point that access to a regular administrative and administrative organization would only be possible if the state and the government had the basis in law. Thus, the main purpose of the constitutional establishment of a constitutional government was to adhere to a set of independent legal rules Which is governed by government.

\section{After the Islamic Revolution of Iran}

With the victory of the Islamic Revolution in Iran in 1979, criminal law will enter the fourth stage of its transformation. This course is a major difference with previous periods. In this era of Islamic rule and implementation of religious law in society. In fact, the Islamic Revolution should be aimed at returning to Islamic jurisprudence which, in all aspects of social life, enables people to accept the happiness of the world and the hereafter as one of its followers and can be a specimen and a taste for other Muslim nations and nations. Similarly, the new political system, called "Islamic Republic of Iran", based on Islamic criteria and principles, while also exploiting the system of separation of powers, was initiated in Iran in accordance with Article 57 of the AHIA. A new stage in Iran's legal system, especially law.

The first detailed law that was written after the revolution with a religious figure in the Qur'an was approved in 1361. This law is from Q. 1352 and the concepts of the 1304 and 1352 laws are completely forgotten. In this law (Article 7), punishment is divided into four types according to the type of crime:

1. retribution

2. blood money

3. comments

The criminal law of Islam is based on the review of illegal acts (offenses) and their violations in the Islamic law. Haram and Turkish are considered to be criminal offenses. Amendments to the laws and regulations are in the form of five titles: the knowledge of religion and the essence, name and generation. Every act that harms one of these materials is a crime. For this reason, adultery and adherence to chastity are considered a crime for the sake of maintaining generosity and honor. Murder and robbery are considered a crime for reasons of its sanction to the lives and property of the people. Khmer and other things are forbidden because of the abandonment of the mind and intelligence of human beings. It is a crime and apostasy is also due to incitement of the classes and beliefs of individuals.

\section{Paying blood money for the Rights of the Iranian Penal Sates (Islamic Republic of Iran)}

In Islamic law, the amount of money is determined by the legislator, so that it is from the minimum of injuries to the murder.

The amount of dying of the soul, from which it is called the blood of demons, is the same in all kinds of intentional and unpardonable crimes. In the Q.A.M.A. The authors of that law state the amount and amount of money in six cases. Article 297: "Murder of a Muslim Man is one of the following: The killer is free to choose any of them, and their combination is not allowed: 
1. One hundred and one hundred healthy camels without flaws.

2. Two hundred healthy cows without defects that are not very lean.

3. One day a healthy and uncomplicated sheep that does not look like that.

4. Two hundred hands of healthy clothes from Yemen.

5. One thousand dinars of pure and unclean dirty tricolor, each dinar of which is an equivalent of gold to 18 peas.

Six decades, a healthy and non-aggressive mosquito, each of which has a dust of 12.6 green peas.

Note: The price of each of the six issues is paid out explicitly by the parties and / or the issue of all of them.

And in the case of members' money

Article 375, Clause I, states: "Eliminating two healthy eyes will result in a complete decay, and each of them will be half full blood.

Note: All eyes that are visible are identical in the above judgment, although they are different in terms of weakness, illness and stiffness. Some Islamic jurisprudents have not proven the Yemeni nature of the Hellas and the group basically considers the payment of Hellah as a dime as lacking a valid and correct basis. By examining Article 297, at first it would seem that every six payment methods should be equal to the price, but in practice it is seen that this equality is not observed and the value of the six varieties varies from each other. It can be said that among the six mentioned in the law, there are only three aspects of application and enforcement that include cattle, sheep and camels, and since it is impossible to pay the same amount, it is stipulated that the price of these types is determined by the experts and their cost is paid by the offender. Beginning in 1994, this procedure is started and once every six months or once a year, these livestock are priced. In the last year, the judiciary announced at the beginning of the year the amount of cash for Kamula, which for 2005 was 25 million tomans, thus eliminating any kind of escapes for the life of the choice of the low price of the dye, and a general basis for Dija presented.

\section{Legal application}

-The penalty (criminal aspect) of the money

With regard to the criminal aspect of blood money, it should be noted that when a person looks at the history of human life in the past and studies the legal periods of human life, it becomes clear that the last generations considered the blood to be a form of punishment, after which Islamic law provides regulations in this regard. And suggested. The reasons and bases that can be applied to the criminal aspect of death are as follows:

1. The legislator expressly stipulates that in the Article 12 of the Code, the Diat is punishable, and stipulates that the penalties provided for in this law are 5 types, the limits of reprisal and punishments, punishments and punitive damages, and the order of the money paid by the shareholder For the crime is determined.

2. Article 1 of the Law on the Establishment of Courts of Penalties 1 and 2 and Branches of the Supreme Court of 1368 established that "the criminal courts shall be established in accordance with the provisions of this Law and shall be punishable by the following penalties and not in the jurisdiction of other courts: Executors shall have the following: "Amnesty and retaliation, and punishments and punishments".

The Verdict of Unity on February 5, 18/11/63 The Court of Justice recognized the death penalty as punishment.

3. By the age of $299 \mathrm{BC}$. The murder in months and places of haram causes a concentration in the blood, which is a kind of escalation in punishment due to the desecration of those months. This article stipulates: "Damage for murder If both injuries and deaths occur in one of the four months (Rajab Ziqaeda Ziyaha Muharram) or in the Mecca Temple Shrine, in addition to the six cases referred to in Article 297 as a restitution of punishment One third of each kind that he has chosen has been added, and the rest of the body, although blessed, do not have this decree. "

In contrast to the criminal aspect and the punishment for the blood, there are some reasons why blood money has a civil nature, which is as follows:

2. The provisions of Article 313 of the Criminal Code. Indicating Legislative Opposition with Two Essential Features of Penalties Including Financial Penalties: One is not the personal responsibility of the blood because under certain circumstances relatives and relatives of life are responsible for the payment of the royalties, while the other necessity of paying for it in the specific cases of these two aspects shows that the pious money It is not a purely false punishment, but is intended to prevent the loss of blood and harmful physical harm.

3. The money is paid to the parents of the father and the guardian, and if they are punished, they must be paid to the public treasury.

4. In the event of the deliberate killer's death and death, he shall receive a payment from his property and in the absence of the property of his relatives, and if he is not a relative or have a financial affiliate, he shall be paid from Betalmal, while the punishment shall be abolished with the death of the convicted offender and the offender.blood money for Iran's criminal policy now

Iran's criminal policy is now derived from these sources:

1. The constitution of the GAI, which is the blood of our revolution and our martyrs, in fact defines the principles of criminal policy, both in crime prevention and in crime. The constitution, if it incorporates 
the principles and principles of public law, and includes any general rules of law and principles governing the separation of powers, but the tendency of the ruler in the QAJJ contains principles that are relatively detailed, which indicates that the experts and writers of the law Particular attention has been paid to the issue of criminal policy, including the principle of innocence, the prohibition of torture, respect for the dignity of the human being, even the person in charge of the charge. Therefore, the constitution's mission is not merely to determine the structure and structure of the constituent forces of a political system, but the responsibility of the ministers and the legislature and other branches of government, but also provides for a series of criminal laws.

2. Penal Code: The Islamic Republic of Iran's second law enforcement instrument is the Islamic Penal Code. In this law, there are schemata and rules governing the categorization of crime and punishment.

3. Criminal Procedure Law: A series of internal public rights in which it is necessary, from the time of the crime up to the issuance of the sentence of punishment for committing and enforcing the penalty, the observance of a series of rules and formalities. In criminal matters, the conviction or conviction of the accused involves the issuance of a ruling from the authorities Judicial courts are required to comply with the rules of criminal procedure for the issuance of a judgment. The jurisdiction of the authorities to investigate and prosecute offenses is to determine the jurisdiction of the criminal courts and their formulation of the issues and principles of the criminal justice system. In this case, CIAA 1378 is a prominent example. With this knowledge of Iran's criminal policy, here we intend to study Iran's criminal policy on dying.

Some Iranian jurists consider the criminal aspect to be a dime and consider it to be the same for a fine. One of these jurists says:

"Penalty is a cash that is taken only in the following three cases of the perpetrator in favor of the innocent or the vicar of his law:

2) If he is satisfied (or his lawyer) and the offender who is given a blood donation instead of a retaliation.

1) If it is not possible to observe the similarity of punishment with the crime.

In cases where the law of the ruling decrees.

The Legal Department of the Judiciary has repeatedly referred to the bloody nature of the Qia'is in answering the questions about the blood money, which can be considered in the following applications:

1. Subject to the rule of "Al-Hakam Wali al-Mumta and al-Hakam wali al-Ghaeb", in the absence of access to the accused or his refusal to choose the tribunal's type of tribunal, he will choose one of the types of blood.

2. Due to the criminal nature of the sentence, Dyya is not considered to be a non-financial conviction. Consequently, the arrest of a convicted person is not opposed to the prohibition of arrest of delinquents until his payment or proof of his pardon. Therefore, if she has not escaped and is not available and refuses to pay the dime, her arrest will be free of charge until the payment of the money or proof of his detention is used in accordance with Article 696 of the Code.

3 In accordance with Article 15 of the Code of Civil Procedure, the death is considered a punishment in Islamic law. Therefore, the claim for damages is not received by the court but the claim for damages and losses in accordance with Article 301 of the Code of Civil Procedure is inclusive of costs If the court fails to pay, the court should, according to the opinion of the prosecutor of the relevant area, act in accordance with this article.

Reflection of the legal nature of the money in Iran's judiciary

If we consider Diera to be just a form of punishment, along with its payment, it will be possible to determine the harm caused by the crime and, on the other hand, if it is considered a loss of damages, it will not receive damages in addition to damages.

2. Due to the principle of the personal nature of the punishment, the criminal liability resulting from it is eliminated by the death of the offender. Therefore, if the punishment is cash or financial, they often believe that it can not be demanded from the heirs, but some people are divided and believe that death after the verdict's verdict does not affect cash penalty. But anyway, it's clear that it is a cash penalty that is unfeasible before death. Therefore, if we condemn the death of the defendant, at least before the verdict of the defendant's death, it is null and void, but if it is considered a financial guarantee, even with the death of the offender during the trial, it is permissible to withdraw it from the dwelling as another blood money.

The theory of the minority of judges in the courts of Tehran province: "Given the fact that the legal and legal damages or damages have been inflicted, redundancy is not called" indemnity ". The theory of the majority of the judges in the courts of the province of Tehran: "Dye is a religion that is based on the fault of the incident and, in accordance with Article 271 of the Civil Code, should be paid to his person or to someone who is acting on his behalf, or to someone legally entitled to a bill. Therefore, if the defendant is paid without permission and consent of the injured person for the cost of his treatment to the hospital and the doctor, etc., it is not possible to calculate the exact amount with the blood.

The theory of the majority of judges in the courts of Tehran province:

"If Mujahideenyyah suffers from conventional charges for the crime, including the cost of treatment that is 
redundant in cash, according to the rule of law and the rule of law and the law of civil liability, and Article 12 of the law on the amendment of laws and regulations and the standard adopted in 1992, excess damages It is mandatory to pay the dowry, but it is not required to be liable for work as a result of possible damages, unless the person is the other person. "

\section{Responsible for payment and payment period}

The payment of a cash payment in a deliberate and pessimistic murder is self-imposed. The legislator in Article 304 of the Criminal Code "In a deliberate and pious offense, he is responsible for paying his death money."

In crimes of pure error, if a crime is proved by a confession of life, it is itself obliged to pay the money. Article $305 \mathrm{BC}$ stipulates in this regard in the latter part: "... if it is established by an adherence of a murderer or an offender, it is an oath or an oath." The deadline for payment of the money is not the consensus of the Islamic jurists and is appropriate and appropriate to the nature of the crime and in order to facilitate payment to the appropriate time.

In some cases, a person may suffer a loss in payment of a stipulated payment and demand an appointment. The question raised here is whether the claim for life imprisonment is acceptable before the expiry of the timelimit prescribed for pessimistic or unintentional murders or not. From the jurisprudential point of view, Ayatullah Muhammad Taqi (for example, Azar is in another Deion). In legal terms, since the religion of an individual in this field (Dyya) is an intrinsic religion and debt, and the Islamic Penal Code has also considered it for a certain period of time in a variety of cases, so the conviction of the convicted person against the payment must be made at the time of execution of the judgment and the maturity of the payment, and not before, and the duty of the court is to consider the matter with all the principles and principles, including exceptions to religion, and declare its final judgment. To prevent the final outcome of the execution of the death sentence.

The legislator states in Article 309: "If a murder of an error is proved by the testimony of a just intuition, then the law will be in charge of the blood, but if it is proved by a confession of life, life itself will be the guarantor."

Article 311 BC stipulates. "It is solely for the person liable to pay damages from the crimes committed merely from the point of view of the murder to the position and in the following cases the guarantor is not:

(A) Pure misconduct committed by a person.

(B) The loss of financial value that is obtained in error. "

In cases where the occurrence of a crime stems from the legitimate conduct of the sovereignty, the surety for life is not fixed and the money is paid out of the state budget (state treasury). This state is if the life of the person was not a crime or he did not commit a crime, such as Article 332 "If it turns out that a military officer or a law enforcement officer has executed the order of the law and has not violated any rules, then the guarantor will not be the victim of the victim, and except for cases where the victim or the injured person was not Mahdur al-Dāmī, the money will be biparticipated."

In this case, the legislator is a criminal offender and, in the absence of a criminal offense, he is considered a victim of a steward. If, in accordance with Article 58 of the Criminal Code, the state is obliged to compensate the defendant when he is not guilty of a misdemeanor crime.

In the intentional crimes that have not been retaliated, and with the amnesty of his innocent and his parents has become a dime, the dye should be paid within one year, but in dubious crimes, according to the famous Islamic jurists, Diva must be paid within two years. Although there is no provision in the Islamic Penal Code or other laws regarding the deadline for payment of money from the Government of the Islamic Republic of Iran, but it can be exercised in accordance with Article 302 of the Criminal Code and its rules of conduct for the payment of cash from non-taxable income. 